\title{
Vieroitettujen porsaiden liemiruokinta
}

\author{
Hilkka Siljander-Rasi ${ }^{1)}$, Pasi Laurinen ${ }^{1)}$, Kirsi Partanen ${ }^{1)}$ ja Tarja Pohjanvirta ${ }^{2}$ \\ 1)MTT Sikatalous, Tervamäentie 179,05840 Hyvinkää, etunimi.sukunimi@mtt.fi \\ 2)EELA, Kuopion tutkimusyksikkö, PL 92,70701 Kuopio, tarja.pohjanvirta@eela.fi
}

\section{Johdanto}

Ennen vieroitusta porsaan kiinteän rehu syönti ja veden juonti ovat hyvin vähäisiä. Näiden taitojen oppiminen vieroituksen jälkeen vie muutamia päiviä, jolloin porsaan paino ei juuri nouse tai jopa laskee, kun kudosten rasvavarastoja käytetään energian lähteenä (Le Dividich ja Seve 2000). Porsaiden ruokkiminen liemimäisellä rehulla (kuiva rehu:vesi 1:2,5) vieroituksen jälkeen on parantanut kasvua ja lisännyt rehun syöntiä ja veden saantia kuivaruokintaan verrattuna (Russell ym. 1996). Liemiruokintaputkistossa tapahtuva maitohappokäyminen laskee rehun pH:n 3-4,5:een, mikä on vähentänyt koliformisten bakteerien määrää sekä liemirehussa että porsaiden suolistossa (Russell ym. 1996, Mikkelsen \& Jensen 1997). Liemiruokinnan haittapuolena voi olla suurempi rehun tuhlaantuminen ja karsinoiden huono hygienia. Myös lietelantaa tulee enemmän kuin kuivaruokinnalla (Russell ym. 1996). Liemirehun pitkäaikainen muhittaminen eli fermentointi ennen ruokintaa on huonontanut porsaiden tuotantotuloksia kuivaruokintaan verrattuna. Fermentoinnin aikana syntyy ravintoainetappioita, $\mathrm{mm}$. puhtaat aminohapot häviävät rehusta. Myös haitallisina pidettyjen amiinien määrä lisääntyy (Pedersen 2001).

Liemiruokintalaitteisto on kallis investointi, ja Suomessa sikojen liemiruokintaan onkin siirrytty, jos rehun raaka-aineiksi on saatavilla nestemäisiä sivutuotteita, kuten viljavalkuaisrehuja ja heraa. Viljavalkuaisrehuja käytetään jonkin verran vieroitetuille porsaille, mutta tutkimustietoa niiden soveltuvuudesta porsaiden ruokintaan ei ole. Porsaat ruokitaan useimmiten kuivarehulla 1-2 viikkoa vieroituksesta myös liemiruokintasikaloissa. Siirtyminen liemiruokintaan heti vieroituksen jälkeen voisi olla työtä säästävä ratkaisu.

Tämän tutkimuksen tarkoituksena oli selvittää nestemäisiä sivutuotteita (ohravalkuaisrehu, hera) sisältävän liemimäisen rehun soveltuvuus vieroitettujen porsaiden ruokintaan. Sivutuotteista koostuvaa liemirehua verrattiin ravintoainekoostumukseltaan samanlaiseen, rakeistettuun porsasrehuun. Tarkoituksena oli myös selvittää, kannattaako liemimäiseen rehuun siirtyä heti vieroituksen jälkeen.

\section{Aineisto ja menetelmät}

Kokeessa oli 46 pahnuetta (368 porsasta), jotka vieroitettiin keskimäärin 31 päivän iässä. Kustakin pahnueesta otettiin kokeeseen kahdeksan tasakokoista porsasta. Pahnueet jaettiin vieroitettaessa arpomalla kolmeen koekäsittelyyn: 1) Ruokinta kuivalla rehulla vieroituksesta $25 \mathrm{~kg}: \mathrm{n}$ painoon, 2) Ruokinta kuivalla rehulla 11 päivää vieroituksesta, vaihto liemirehulle viikon aikana, ruokinta liemirehulla kokeen loppuun, 3) Ruokinta liemirehulla vieroituksesta $25 \mathrm{~kg}: n$ painoon. Koe päättyi porsaiden ollessa noin 25 kilon painoisia (9-10 viikon ikäisiä).

Koerehujen raaka-aineet näkyvät taulukossa 1. Liemirehussa korvattiin ohraa ja soijaproteiinia Tähkä-ohravalkuaisrehulla (OVR, Altia Oyj) ja herajauhetta tiivistetyllä heralla $(250 \mathrm{~g} \mathrm{ka} / \mathrm{kg})$. Heran toimitti Polarfarmi Oy. Rehujen ravintoainekoostumus suunniteltiin samanlaiseksi: rehuyksikköarvo $1,2 \mathrm{ry} / \mathrm{kg} \mathrm{ka}$, sulava raakavalkuainen $155 \mathrm{~g} / \mathrm{ry}$, sulava lysiini 9,5 g/ry, sulava metioniini + kystiini 5,6 $\mathrm{g} / \mathrm{ry}$, sulava treoniini $6,1 \mathrm{~g} / \mathrm{ry}$, kalsium $9 \mathrm{~g} / \mathrm{ry}$, ja sulava fosfori $3,2 \mathrm{~g} / \mathrm{ry}$. Liemirehun kuivista raakaaineista tehtiin jauhomainen esiseos, johon hera, ohravalkuaisrehu ja vesi sekoitettiin. Ruokintateknisistä syistä (sekoitusvaunun ja ruokintakaukalon tilavuus) oli tavoitteena, että liemirehussa olisi $280 \mathrm{~g}$ kuiva-ainetta/kg. Liemirehu sekoitettiin 1001 liemirehuvaunussa, jonne jätettiin pohjalle 5-15 1 edellisen ruokintakerran rehua. Rehun aineosat sekoitettiin 30-45 minuuttia ennen ruokintaa ja rehua sekoitettiin vielä muutamia minuutteja ennen ruokintaa. Yöksi vaunu tyhjennettiin ja huuhdeltiin.

Kuiva rehu tarjottiin vapaasti automaateista ja liemirehu kaukaloista neljä kertaa päivässä, klo $7.00,10.00,13.00$ ja 15.30 . Suunniteltu liemirehuannos oli 0,5 ry-1,2 ry/porsas/pv, mutta annoksia muutettiin porsaiden ruokahalun mukaan. Kaukaloissa oli ruokintatilan (noin $15 \mathrm{~cm} /$ porsas) erottajat rehun tuhlaantumisen estämiseksi. Ryhmän 2 porsaat totutettiin liemirehulle 12.-17. päivinä vieroituksesta niin, että karsinoissa oli kuivarehuautomaatit 15.30-8.00 välisenä aikana ja päivällä porsaat ruokittiin kaukaloista liemellä klo 10.00 ja 13.00. Rehun kulutus mitattiin viikoittain.

Ripulin esiintymistä tarkkailtiin päivittäin. Ripulijakson kestoksi katsottiin ensimmäisen ja viimeisen ripulihavainnon välinen aika. Ripuli-indeksi laskettiin kaavalla indeksi $=\Sigma$ (ulosteen kiinteysaste 
(0-3) x esiintyminen, pv). Jokaisen karsinan kolmelta porsaalta (samat joka kerta) kerättiin sontanäytteet 5., 13., ja 20. päivänä vieroituksesta. Sontanäytteistä määritettiin kuiva-aine ja EELA:ssa koliformisten bakteerien määrä soveltaen NMKL 44:1995, ISO 4832:1991 -menetelmää (laimennussarja ulosteista, maljavalu VRB-agariin, VRB pintavalu). Hemolysoivien kolien osuus määritettiin tekemällä ulostelaimennoksista pintalevitys verimaljoille. Ripulia aiheuttavien kolien tunnistus tehtiin viljelemällä näytteistä lisäksi suora pintalevitys EMB- ja verimaljalle. EMB-maljalta nähdään kolibakteerien osuus koliformeista bakteereista. Verimaljan hemolyyttisistä pesäkkeistä (4/näyte) osoitettiin $E$. colibakteerin enterotoksiinien geenit PCR-menetelmällä. Toisessa tutkimuksessa osoitettiin lämpölabiilin toksiinin (LT) ja lämpöstabiilien toksiinien (ST1 ja ST2) geenit samassa monistusreaktiossa ja toisessa tutkimuksessa etsittiin ödeematautitoksiinin (Stx2e) geeniä.

Kuivaruokintaryhmästä 1 ja liemiruokintaryhmästä 3 teurastettiin molemmista 5 porsasta kokeen päätyttyä ja mahalaukuista tutkittiin limakalvomuutokset.

Liemirehun $\mathrm{pH}$ ja kuiva-aine mitattiin viikoittain ja ominaispaino määritettiin punnitsemalla päivittäin litra rehua ruokinnan alussa ja lopussa. Kokeen aikana kerätyistä rehunäytteistä määritettiin kuiva-aine, tuhka, raakavalkuainen, raakarasva ja raakakuitu sekä aminohapot. Liemirehusta määritettiin lisäksi maitohappo, haihtuvat rasvahapot ja etanoli.

Aineiston tilastollinen analysointi tehtiin SAS-ohjelmistolla (GLM). Tilastollisessa mallissa testattiin koeryhmän vaikutusta. Havaintoyksikkönä oli karsina. Ryhmien väliset erot testattiin ortogonaalisin kontrastein 1) kuivarehu vs. liemirehu (ryhmä 1 vs. ryhmät 2 ja 3 ) ja 2) osittainen liemirehuruokinta vs. liemirehuruokinta vieroituksesta alkaen (ryhmä 2 vs. ryhmä 3 ).

Taulukko 1. Koerehujen raaka-aineet ja analysoitu koostumus (g/kg ka).

\begin{tabular}{lcc}
\hline & Kuivarehu & Liemirehu \\
\hline Ohra & 245,6 & 139,5 \\
Vehnä & 400,0 & 400,0 \\
Kasviöljy & 30,0 & 30,0 \\
Herajauhe & 100,0 & - \\
Hera (250 g ka/kg) & - & 100,0 \\
Heraproteiini (750 g RV/kg) & 30,0 & 30,0 \\
Soijaproteiini & 157,0 & 59,4 \\
Tähkä-ohravalkuaisrehu & - & 200,0 \\
L-lysiini-HCl & 1,8 & 4,1 \\
DL-metioniini & 0,3 & 0,3 \\
L-treoniini & - & 0,6 \\
Ruokintakalkki & 13,4 & 15,0 \\
Monokalsiumfosfaatti & 6,9 & 5,8 \\
Kivennäis-vitamiiniseos & 15,1 & 15,2 \\
Analysoitu koostumus & & \\
Raakavalkuainen & 220,5 & 217,0 \\
Lysiini & 12,1 & 12,1 \\
Metioniini + kystiini & 7,5 & 7,3 \\
Treoniini & 8,8 & 8,3 \\
Tuhka & 66,0 & 69,4 \\
\hline
\end{tabular}

\section{Tulokset ja tulosten tarkastelu}

Kuiva- ja liemirehun analysoitu koostumus oli hyvin samanlainen (Taulukko 1). Liemirehuseoksessa oli kuiva-ainetta keskimäärin 292,6 g/kg ka (258,2-320,4 g/kg ka). Liemiruokintalaitteistoa käytettäessä liemen kuiva-ainepitoisuuden määrää rehun kulkevuus putkistossa. Liemirehun pieni kuiva-ainepitoisuus $(<250 \mathrm{~g} \mathrm{ka} / \mathrm{kg})$ voi rajoittaa porsaiden kuiva-aineen saantia kaksi viikkoa vieroituksesta (Geary ym. 1996). Liemirehun pH oli keskimäärin 4,56 (4,35-4,76) ja ominaispaino 1,08 kg/l. Liemirehu sisälsi pieniä määriä orgaanisia happoja, lähinnä etikkahappoa $(3,3 \mathrm{~g} / \mathrm{kg} \mathrm{ka})$ ja maitohappoa $(13,2 \mathrm{~g} / \mathrm{kg} \mathrm{ka})$. Myös vähäistä etanolin muodostusta havaittiin $(0,51 \mathrm{~g} / \mathrm{kg} \mathrm{ka})$. Maitohappokäymisen varmistamiseksi ja haitallisten bakteerien (E. coli, Salmonella) kasvun estämiseksi liemirehun pH:n tulisi olla 4,0-4,5. Jos maitohappokäyminen häiriintyy, $\mathrm{mm}$. hiivat voivat lisääntyä haitallisesti ja rehun maittavuus huonontua (Brooks ym. 2001).

Liemirehuryhmien pahnueet olivat vieroitettaessa keskimäärin 2,3 päivää nuorempia kuin kuivaruokintaryhmän pahnueet ( $<00,001$; Taulukko 2$)$. Koepahnueet vieroitettiin ryhmissä ja ne olivat peräisin useista eri vieroituseristä, mikä aiheutti eroja niiden todellisiin vieroitusikiin. Liemirehuryh- 
mien porsaat olivat kevyempiä kuin kuivaruokintaryhmän porsaat sekä vieroitettaessa $(p<0,05)$ että 11 päivän kuluttua vieroituksesta $(\mathrm{p}=0,06)$. Myöhemmin porsaiden painoerot tasoittuivat.

Suoraan liemirehulle vieroitettujen porsaiden päiväkasvu oli 11 päivää vieroituksesta huonompi kuin kuivaa rehua saaneiden porsaiden, mutta ero ei ollut merkitsevä. Myöhemmin liemiryhmien porsaat kasvoivat kuivaruokintaryhmää paremmin, ja niiden koko kokeen aikainen päiväkasvu oli parempi kuin kuivalla rehulla ruokittujen porsaiden $(\mathrm{p}<0,05)$. Alussa kuivaa rehua saaneiden ja koko ajan liemellä ruokittujen porsaiden päiväkasvussa ei ollut eroa.

Koerehujen maittavuus oli hyvä. Liemirehun syöntiin tottuminen tosin vaihteli pahnueiden välillä. Päivää kohti laskettu kuiva-aineen syönti oli samanlainen kuiva- ja liemirehulla ruokittaessa. Koko ajan liemellä ruokittujen porsaiden rehunkulutus oli $50 \mathrm{~g} \mathrm{ka} /$ porsas/pv pienempi kuin alussa kuivaa rehua saaneiden porsaiden $(\mathrm{p}=0,08)$, mikä johtui niiden vähäisemmästä rehun syönnistä heti vieroituksen jälkeen. Porsaiden rehuhyötysuhde oli parempi liemirehulla kuin kuivarehulla ruokittaessa $(\mathrm{p}<0,001)$ ja kokonaan liemiruokituilla porsailla parempi kuin alussa kuivaa rehua saaneilla $(\mathrm{p}<0,01)$. Osa rehuhyötysuhteen eroista voi selittyä kuivarehun suuremmalla tuhlaantumisella automaateista. Lattialle joutuneen rehun määrää ei pystytty mittaamaan. Tulokset ovat yhdenmukaisia aikaisempien tutkimusten kanssa (Russell ym. 1996, Brooks ym. 2001). Yhtenä selityksenä parempaan kasvuun ja rehunkäyttöön liemiruokinnalla voi olla lisääntynyt veden saanti ja sen ansiosta parempi ravintoaineiden sulavuus (Barber ym. 1991). Jos rehun annostelutapa, lähinnä ruokintakaukalon rakenne, on epäonnistunut, liemirehun tuhlaus voi olla huomattavaa (Russell ym. 1996).

Taulukko 2. Porsaiden kasvu ja rehunkäyttö kuiva- ja liemirehulla ruokittaessa.

\begin{tabular}{|c|c|c|c|c|c|c|}
\hline \multirow[b]{2}{*}{ Rehun tyyppi } & \multirow{2}{*}{$\frac{\text { Ryhmä } 1}{\text { Kuiva }}$} & \multirow{2}{*}{$\begin{array}{l}\text { Ryhmä } 2 \\
\text { Kuiva + Liemi }\end{array}$} & \multicolumn{2}{|l|}{ Ryhmä 3} & \multicolumn{2}{|c|}{ Tilastollinen merkitsevyys } \\
\hline & & & Liemi & SEM & R1 vs R2+R3 & R2 vs R3 \\
\hline Vieroitusikä, pv & 32,5 & 31,1 & 30,2 & 0,26 & $* * *$ & $*$ \\
\hline \multicolumn{7}{|l|}{ Porsaan paino, $\mathrm{kg}$} \\
\hline Vieroitettaessa & 11,3 & 10,2 & 10,1 & 0,44 & $*$ & \\
\hline $11 \mathrm{pv}$ vieroituksesta & 13,5 & 12,4 & 11,9 & 0,61 & $\mathrm{o}$ & \\
\hline 25 pv vieroituksesta & 20,7 & 20,2 & 20,5 & 1,06 & & \\
\hline Kokeen päättyessä & 26,9 & 27,1 & 27,7 & 0,62 & & \\
\hline \multicolumn{7}{|l|}{ Päiväkasvu, g } \\
\hline $11 \mathrm{pv}$ vieroituksesta & 204 & 196 & 161 & 22,9 & & \\
\hline $12-25 \mathrm{pv}$ vieroituksesta & 512 & 560 & 618 & 40,1 & & \\
\hline Koko koeaikana & 463 & 502 & 524 & 19,7 & $*$ & \\
\hline Päiviä kokeessa & 33,9 & 33,9 & 34,2 & 1,21 & & \\
\hline $\mathrm{Kg}$ rehun $\mathrm{ka} /$ porsas/pv & 0,80 & 0,79 & 0,74 & 0,03 & & o \\
\hline \multicolumn{7}{|l|}{ Rehuhyötysuhde, ry/kg } \\
\hline $11 \mathrm{pv}$ vieroituksesta & 2,90 & 3,53 & 2,89 & 0,45 & & \\
\hline $12-25 \mathrm{pv}$ vieroituksesta & 2,04 & 1,76 & 1,51 & 0,07 & $* * *$ & $* *$ \\
\hline Koko koeaikana & 2,08 & 1,97 & 1,78 & 0,05 & $* * *$ & $* *$ \\
\hline
\end{tabular}

Osalla porsaista oli kokeen aikana vieroitusripulia, mutta ripulin keskimääräisessä kestossa ei ollut eroa kuivarehu- ja liemirehuruokinnan välillä ( 9,9 vs. 12,3 pv). Aluksi kuivalla rehulla ruokituilla porsailla ripulihavainnot ajoittuivat pidemmälle aikavälille kuin kokonaan liemellä ruokituilla porsailla $(15,9$ vs. 8,7 pv; $p<0,01)$, koska rehun vaihdon jälkeisinä päivinä niiden uloste oli löysempää. Ripuli-indeksissä ei ollut eroa kuiva- ja liemiruokinnan välillä $(13,8$ vs. 13,2$)$, mutta indeksi oli suurempi osittain liemiruokituilla kuin täysin liemiruokituilla porsailla $(15,8$ vs.10,6; $\mathrm{p}=0,08)$. Ripulilääkitys annettiin 27 porsaalle 368:sta. Lääkittyjen porsaiden määrä ei poikennut ryhmien välillä.

Taulukko 3. Porsaiden sonnan vesipitoisuus ja $E$. coli -bakteerien kokonaismäärä vieroituksen jälkeen.

\begin{tabular}{|c|c|c|c|c|c|c|}
\hline \multirow[b]{2}{*}{ Rehun tyyppi } & Ryhmä 1 & Ryhmä 2 & Ryhmä 3 & \multicolumn{3}{|c|}{ Tilastollinen merkitsevyys } \\
\hline & Kuiva & Kuiva + Liemi & Liemi & SEM & R1 vs R2+R3 & R2 vs R3 \\
\hline Sonnan vesipitoisuus, $\mathrm{g} / \mathrm{kg}$ & & & & & & \\
\hline 5 pv vieroituksesta & 744 & 732 & 784 & 1,16 & & $* *$ \\
\hline 13 pv vieroituksesta & 737 & 755 & 743 & 0,59 & & \\
\hline $20 \mathrm{pv}$ vieroituksesta & 737 & 751 & 746 & 0,67 & & \\
\hline Sonnan $E$. colit, $\log \mathrm{pmy} / \mathrm{g}$ & & & & & & \\
\hline 5 pv vieroituksesta & 7,3 & 7,3 & 7,4 & 0,36 & & \\
\hline $13 \mathrm{pv}$ vieroituksesta & 6,4 & 7,0 & 6,3 & 0,38 & & \\
\hline 20 pv vieroituksesta & 5,3 & 6,0 & 4,6 & 0,25 & & $* * *$ \\
\hline
\end{tabular}


Porsaiden sonnan vesipitoisuus ei poikennut kuivaruokinta- liemiruokintaryhmien välillä (Taulukko 3). Täysin liemiruokittujen porsaiden sonnan vesipitoisuus oli suurempi 5. päivänä vieroituksesta kuin osittain liemiruokittujen, jotka ruokittiin tuolloin vielä kuivalla rehulla. Sonnan E. coli bakteerien kokonaismäärissä ei ollut eroa ruokintojen välillä 5. ja 13. päivänä vieroituksesta, mutta 20. päivänä vieroituksesta osittain liemiruokittujen porsaiden sonnassa oli enemmän koleja kuin täysin liemiruokittujen $(\mathrm{p}<0,001)$.

Tässä tutkimuksessa 53,1\%:ssa näytteistä ei ollut lainkaan hemolyyttisiä koleja. Vähiten puhtaita näytteitä oli osittain liemiruokitulla ryhmällä. Vieroitusripulinäytteissä hemolyyttisten $E$. coli bakteerien osuus kokonaiskoleista on yleensä 90-100 \%. Tällaisia näytteitä löytyi tutkituista kaikkiaan 19,7 \% (26/132). Kahta näytettä lukuun ottamatta (ryhmä 2) nämä näytteet oli otettu 5. ja 13. päivänä vieroituksesta. Osittain liemiruokittujen porsaiden sonnassa oli liemiruokinnan alussa (13. päivänä vieroituksesta) hemolyyttisten kolien osuus (43,5 \%) suurempi kuin koko ajan kuivaruokinnalla $(25,3$ $\%)$ tai liemiruokinnalla $(18,6 \%)$ olleiden porsaiden sonnassa. Tulos on yhdenmukainen silmämääräisesti tehdyn ripuliarvioinnin kanssa. Liemiruokinnan on useissa tutkimuksissa havaittu lisäävän maitohapon määrää ja vähentävän kolibakteerien määrää porsaiden suolistossa kuivaruokintaan verrattuna (Brooks ym. 2001, Mikkelsen \& Jensen 1997).

PCR-analyysin perusteella osalla hemolyyttisistä koleista ei ollut lainkaan ripulia aiheuttavien toksiinien geenejä (12/128). Yleisimmin ripulin aiheuttavat LT1, ST2 tai ST1,ST2 -toksiinit Samoista näytteistä voi löytyä myös molempia toksiiniyhdistelmiä (Bertschinger \& Fairbrother 1999).

Mahalaukun limakalvojen tutkimusta varten teurastetut porsaat olivat ulkoisesti terveitä ja hyvin kasvaneita. Kuitenkin puolella porsaista löytyi eriasteisia limakalvomuutoksia, joista vakaviksi arvioitiin 2/5 sekä kuiva- että liemiruokintaryhmissä. Mahahaavoja ei erikseen seurattu enää teurasvaiheessa, mutta kokeessa olleilla porsailla ei havaittu myöhemmin mahahaavaan viittaavia ulkoisia oireita tai kuolleisuutta. Sikojen mahahaavan arvellaan johtuvan useiden tekijöiden yhteisvaikutuksesta. Tällaisia ovat mm. hienoksi jauhetun rehuviljan käyttö ja sikojen kokema stressi ja muut sairaudet.

\section{Johtopäätökset}

Tuotantotulosten perusteella nestemäisiä sivutuotteita sisältävä liemirehu sopi porsaille yhtä hyvin kuin ravintoainekoostumukseltaan sitä vastaava kuivaruokinta. Porsaiden vieroittamisesta kuivaruokinnalle ja siirtämisestä vasta myöhemmin liemelle ei ollut etua verrattuna vieroituksesta aloitettuun liemiruokintaan.

Jos porsaat vieroitetaan liemiruokinnalle, ripulin ennaltaehkäisy ja rehuhygienia ovat tärkeitä, koska riski ripuliin on olemassa. Liemirehuruokinnan jatkuessa sonnan kolibakteerien määrä ja ripulisuus vähenivät. Aluksi kuivaruokinnalla olleiden porsaiden siirto liemelle lisäsi ripulisuutta, mikä näkyi myös mikrobiologisissa määrityksissä.

Tutkimuksessa havaittu mahan limakalvomuutosten esiintyminen porsailla vaatii lisäselvityksiä. Muutoksia esiintyi sekä kuiva- että liemiruokinnalla.

\section{Kirjallisuus}

Barber, J., Brooks, P.H. \& Carpenter, J.L. 1991. The effects of water to food ratio on the digestibility, digestible energy and nitrogen retention of a grower ration. Anim. Prod. 52: 601.

Bertschinger, H.U. \& Fairbrother, J.M. 1999. Escherichia coli infections. In: Straw, B.E., D'Allaire, S., Mengeling, W.L. \&Taylor, D.J. (eds.). Diseases of Swine, $8^{\text {th }}$ ed. Iowa State University Press, USA. p. 431-468.

Brooks, P.H., Moran, C.A., Beal, J.D., Demeckova, V. \& Campbell, A. 2000. Liquid feeding of the young piglet. In: Varley, M.A. \& Wiseman, J. (eds.). The weaner pig: nutrition and management. CABI Publishing, UK. p. 153-178.

Geary, T.M., Brooks, P.H., Morgan, D.T., Campbell, A. \& Russell, P.J. 1996. Performance of weaner pigs fed ad libitum with liquid feed at different dry matter concentrations. J.Sci. Food Agric. 72: 17-24.

Le Dividich, J. \& Sève, B. 2000. Effect of underfeeding during the weaning period on growth, metabolism, and hormonal adjustments in the piglet. Domest. Anim. Endocrinol. 19: 63-74.

Mikkelsen, L.L. \& Jensen, B.B. 1997. Effect of fermented liquid feed (FLF) on the growth performance and microbial activity in the gastrointestinal tract on weaned piglets. In: Digestive Physiology in Pigs. EAAP Publication no. 88. p 639-642.

Pedersen, A.Ø. 2001. Fermenteret vådfoder til smågrise. Landsudvalget for Svin. Meddelelse Nr. 510. København. $22 \mathrm{p}$.

Russell, P.J., Geary, T.M., Brooks, P.H. \& Campbell, A. 1996. Performance, water use and effluent output of weaner pigs fed ad libitum with either dry pellets or liquid feed and the role of microbial activity in the liquid feed. J.Sci. Food Agric. 72: 8-16. 